\title{
EFFECTIVENESS OF YOGA MOVEMENT "SURYANAMASKAR" OF DYSMENORRHOEA PAIN REDUCTION OF ADOLESCENT
}

\author{
Levi Tina Sari \\ Midwifery Department, Patria Husada Blitar School of Health Science \\ email: tinasari.levi@gmail.com
}

\begin{abstract}
In adolescence, a physical phenomenon associated with puberty is in biological processes that lead to the ability to reproduce years marked by menstruation, some women must have experienced pain during menstruation in the form of pain. The purpose of this research was to analyze the effectiveness of yoga suryanamaskar movement to decrease dysmenorrhea pain of adolescent girls. This research used pre-post design, with 20 respondents of the 27 total population. The research was measured by pain scale $0-10$ with data analysis using paired sample t-test. The results showed that there was an average increase before and after the intervention of 3.5 points. Test results obtained $\tilde{n} \hat{A}$ á means there was a significant difference between before and after treatment. Yoga suryanamaskar combines motion, breathing and relaxation techniques, which aimed to feel comfortable. Yoga with body suryanamaskar movement required adequate oxygen intake in order to burn glucose into ATP and burn fat in the body, at that time endorphin hormone appears in order to provide pain relief. So it can be recommended to adolescents as training to reduce dysmenorrhea disk.
\end{abstract}

Keywords: yoga suryanamaskar, adolescent, dysmenorrhea

\section{INTRODUCTION}

Adolescence, where there is a period of transition from childhood to adulthood is a dynamic phase of development in life. According Sarwono (2003), that adolescents develop, from secondary sexual signs, psychological and patterns of identification of children to adulthood. Where there is a physical phenomenon associated with puberty is the biological process that leads to the ability to reproduce. Puberty in adolescents generally occurs at the age of 9-15 years characterized by menstruation. Menstruation is part of a regular process that prepares a woman's body every month for pregnancy, which is controlled by hormonal interactions issued by the hypothalamus, the pituitary gland, and the ovaries.

In general, women experience physical discomfort for several days before the menstrual period comes. Some women must have experienced pain during menstrual periods of pain (Proverawati $\&$ Misaroh 2009). Pain during menstruation in medical terms is called Dysmenorrhea. Studies show that the hormone prostaglandin plays an important role in the etiology of primary dysmenorrhoea because this hormone plays an important role in the contraction of the myometrium that is useful for shedding the endometrial layer so start the menstrual process followed by mild bleeding. If the hormone prostaglandin is released in large amounts of eating will occur pain and some other effects that are nausea, vomiting, and diarrhea.

According to Yatim (2001), His statement are dysmenorrhea is a pain in menstrual periods in the pelvic region due to increased prostaglandin hormone. It often starts after the first menstruation (menarche). The cause of pain comes from the uterine muscles, as all uterine muscles can contract and relax. When menstruation is stronger contractions. Contractions that occur due to a substance called prostaglandin. Prostaglandins are made by the inner lining of the uterus. Before menstruation occurs this substance increases and 
as soon as menstruation occurs, prostaglandin levels decrease (Kirana, 2011). This dysmenorrhea occurs between the ages of 15-25 years and then disappears in late age in the early 30 s. Pain usually occurs several hours before the menstrual period and can continue up to 48-72 hours. Pain decreases after menstruation. Pain during menstruation causes discomfort in daily physical activity.

The incidence of primary menstrual pain in Indonesia is about $54.89 \%$, while the rest are patients with secondary type. United States is estimated almost $90 \%$ of adolescents experience menstrual pain $10-15 \%$ of them experience severe menstrual pain, which causes them not able to perform any activity and this will reduce the quality of life in each individual. The incidence of dysmenorrhoea in Indonesia is $64.25 \%$ consisting of $54.89 \%$ primary dysmenorrhoea and $9.36 \%$ secondary dysmenorrhoea (Andira, 2013)

According to Munandar (2013), His statement are during adolescence there is a typical emotional tension so that this period is called the storm and storm (storm and stress) heightened emotionality, a period that describes the emotional state in adolescents are erratic, unstable, and explodeexplosive, faced with the search for knowledge of himself, what and where and how about himself. Thus, if not immediately addressed will affect the mental and physical function of adolescents, therefore there is action traditional therapy, one of which is using yoga suryanamaskar.

Yoga suryanamaskar is an ancient yoga movement which has three aspects namely form, vital energy and rhythm (Wong, 2011 cited Renityas, 2017). yoga is one of the relaxation techniques that can be used to reduce pain because while doing gymnastics, brain and spinal cord arrangement will produce endorphin, a hormone that serves as a natural sedative and cause a sense of comfort. (Akmarawita, 2010). In addition, relaxation techniques in yoga can stimulate the body to rele ase endogenous opioid that is endorphin and enkephalin (a compound that works to inhibits pain), then with it, yoga is useful when menstruating. The menstrual cycle is related to the hormonal interconnection chain that occurs in women during menstruation every month, the sequence of events allows the egg (Rohimawati, 2011).

Based on the description above researchers interested to examine the effectiveness of yoga movement suryanamaskar to decrease pain dysmenorrhoea in young women in STIKes Patria Husada Blitar. The purpose of this study were (1). Knowing dysmenorrhea pain before treatment in young women, (2). Knowing dysmenorrhea pain after treatment in young women, (3). Analyze the effectiveness of yoga suryanamaskar movement to decrease dysmenorrhea pain in adolescent girls.

\section{METHOD}

Research design using experimental pre using one group pre-post design approach that is giving treatment of yoga Suryanamaskar movement to the intensity of pain at the time of menstruation then measured pain intensity before and after technique of yoga suryanamaskar movement. The population of this study are young women enrolled Husada STIKes Patria Blitar. Sampling using purposive sampling with inclusion criteria include young women ages 18-20 years, primary Dysmenorrhoea experiencing pain, then obtained a sample of 20 respondents out of a total population of 27 young women.

Measurement of pain response using the scale numeric pain rating scale that ranges from 0-10. Dysmenorrhoea pain level will be measured using a numerical scale observation sheet to be filled out by respondents when experiencing pain Dysmenorrhoea, then researchers conducted as much as $6 \mathrm{x}$ treatment for 2 weeks (one week $3 \mathrm{x}$ treatment) at the end of the treatment the researchers gave a questionnaire containing sheet scale pain to the respondent.

The scale of the data used is the scale interval with a value of 0 no pain, 1-4 mild pain, 5-7 moderate pain, severe pain 8-10. Analysis of the data used in this study include univariate analysis using frequency distribution and bivariate analysis using paired samples t-test.

\section{RESULT}

\section{General data}

Respondents in this study has the following characteristics:

Table 1 Characteristics of Respondents

\begin{tabular}{lll}
\hline Characteristics & $\Sigma$ & \% \\
\hline Age (year) & & \\
18 & 5 & 25 \\
19 & 8 & 40 \\
20 & 7 & 35 \\
\hline
\end{tabular}




\begin{tabular}{lcc}
\hline Characteristics & $\Sigma$ & $\%$ \\
\hline Menstrual History & & \\
Regular & 11 & 55 \\
Irregular & 9 & 45 \\
\hline History exercising & & \\
Regular & 5 & 25 \\
Irregular & 15 & 75 \\
\hline The first menstrual period (year) & & \\
$>12$ & 8 & 40 \\
$12-14$ & 7 & 35 \\
$>14$ & 5 & 25 \\
\hline
\end{tabular}

Based on the data above states that the greatest age was 19 out and 11 respondents have a regular menstrual history but only 5 respondents who exercise regularly, and age of first menstrual period experienced by those aged $>12$ years as many as 8 respondents.

\section{General data}

Achievement acuyoga movement on young girls in pain reduction Dismenorhea.

Table 2 Frequency Distribution of Respondents Prior Treatment Guide

\begin{tabular}{lcc}
\hline Pain Scale & $\Sigma$ & \% \\
\hline No Pain & 0 & 0 \\
Mild pain & 5 & 25 \\
Moderate pain & 11 & 55 \\
Severe pain & 4 & 20 \\
\hline
\end{tabular}

Based on the above table proves that 11 respondents had moderate pain and 4 respondents experiencing severe pain.

Table 3 Frequency Distribution of Respondents After Treatment Guide

\begin{tabular}{lcc}
\hline Pain Scale & $\Sigma$ & \% \\
\hline No Pain & 6 & 30 \\
Mild pain & 10 & 50 \\
Moderate pain & 4 & 20 \\
Severe pain & 0 & 0 \\
\hline
\end{tabular}

Based on the above table proves that 10 respondents experienced mild pain and 6 respondents expressed no pain.
Table 4 Descriptive Numerical Value and Paired Sample t-test Test of Effectiveness of Suryanamaskar Movement on Pain Reduction of Dismenorrhea

\begin{tabular}{lcccc}
\hline Treatment & $\mathbf{N}$ & Mean & $\begin{array}{c}\text { Mean } \pm \text { Std. } \\
\text { deviasi }\end{array}$ & $\boldsymbol{\rho}$ \\
\hline Before & 20 & 5,95 & $3,500 \pm 0.946$ & 0.000 \\
\cline { 1 - 3 } After & 20 & 2,45 & & \\
\hline
\end{tabular}

Based on the above table there is an increase on average before and after the intervention by 3.5 points. The test results obtained $\tilde{n} \hat{A}$ á value means there is a significant difference between before and after treatment.

\section{DISCUSSION}

\section{Analysis of Dismenorhea Pain Before Giving a Motion of Yoga Suryanamaskar}

Based on the results of research proves that young women experience dysmenorrheal pain, even to the category of severe pain. Menstrual pain is also influenced by several factors: his long periods of time, early menarche age, and sports history and psychology.

Dysmenorrhea will appear if there is a myometrial dysrhythmic contraction featuring one or more symptoms, ranging from mild to severe pain at the bottom, buttocks, and spasmodic pain to the medial side of the thigh (Anurogo and Wulandari, 20110). Then, according to Reeder (2013), states that the increase in prostaglandin and its release (PGF2á) from the endometrium during menstruation causes uncoordinated and irregular uterine contractions that cause pain. During the menarche period, respondents who had a history of dysmenorrhea had higher intrauterine pressure and had twice the prostaglandin levels. In adolescent girls who experience primary dysmenorrhoea increased levels of vasopressin, causing hypoxia and uterine ischemia. Then in adolescent girls who experienced primary dysmenorrhoea but did not increase the level of prostaglandin, then there will be increased activity of 5-lipoksigenase groove. This increases the synthesis of leukotriene, a very strong vasoconstrictor that induces uterine muscle (Reeder, 2013).

Lack of exercise is also one of the factors affected by dysmenorrhea, this is because someone 
who exercise will release the hormone endorphins, endorphins are endogenous peptide opioids that function as neurotransmitters and have the same structure with morphine, so as to relieve pain (Rokade, 2011).

\section{Analysis of Pain Dysmenorrhea After Given Yoga Surya Namaskar Movement}

Based on the results that yoga can reduce the pain of dysmenorrhea who do as much as $6 \mathrm{x}$ in 2 weeks. This is because the hormone endorphin continuously so as to reduce pain.

According Akmarawita (2010), yoga is one of the relaxation techniques that can be used to reduce pain because while doing gymnastics, brain and spinal cord arrangement will produce endorphin, a hormone that serves as a natural sedative and cause a sense of comfort. Moreover, it also provides benefits to maintain the balance of the abdominal muscles and increase energy thus increases oxygen supply and an impact on the body's energy.

Yoga suryanamaskar have movements that can tighten the muscles and joints as well as maintaining the balance of the abdominal muscles so that the oxygen supply is increasing and can reduce pain.

\section{Yoga Suryanamaskar Movement Analysis To Decrease Pain Dysmenorrhea}

The results proved that yoga suryanamaskar movement can reduce dismenorhea pain in young women. Due to the ongoing training and mentoring of researchers that yoga movements right, it can improve blood circulation throughout the body, increase lung capacity, reduce tension both physical and mental body so that it can reduce pain. Besides the conduct yoga regularly can reduce the liquid that has accumulated at the waist so that it can reduce pain Dismenorhea (Suratini, 2013).

Yoga suryanamaskar combines motion, breathing and relaxation techniques, which aim to comfort. Yoga with suryanamaskar movement of the body needs more oxygen and adequate in order to burn the glucose into ATP and burn fat in the body, when the hormone endorphin appears in order to provide pain relief. Relaxation techniques in yoga exercises can stimulate the body's release of endogenous opioids that endorphins and enkephalins (compounds that function to inhibit pain), then by that yoga is beneficial when menstruating.

In the peripheral nervous system, producing analgesic endorphins by binding to opioid receptors in both pre- and post-synaptic nerve terminals. When binding, there will be a cascade of interactions that lead to inhibition of tachycin release, especially $P$ substance involved in pain transmission. In the central nervous system, endorphins endorphins direct their primary action to the presinaptic nerve terminals. However, the endorphins do not inhibit substance $P$, but inhibits the release of gammaaminobutyric acid (GABA). The inhibition will lead to increased dopamine production associated with pleasure (Blum, 2010)

The hormone endorphins that are produced when performing yoga movements regularly then flowed throughout the body. Endorphin hormone acts as a natural analgesic in the body. Endorphins will control the condition returns to normal blood vessels and keep blood stream can flow unimpeded (Sormin, 2014).

\section{CONCLUSION AND SUGGESTION}

\section{Conclusion}

Yoga with body suryanamaskar movement requires adequate oxygen intake in order to burn glucose into ATP and burn fat in the body, at that time endorphin hormone appears in order to provide pain relief. So it can be recommended to adolescents as training to reduce dysmenorrhea.

\section{Suggestion}

As a health practitioner will consider yoga suryanamaskar as a complementary therapy that can reduce dismenorrhea pain. And respondents can also reduce chemical drugs in reducing dysmenorrhea pain.

\section{REFERENCES}

Akmarawita, K. 2010. Hormones Changes to Stress. Jurnal Ilmiah Kedokteran Wijaya Kusuma Vol 2, No 1. hh. 73-85

Andira,D. 2010. Seluk Beluk Kesehatan Reproduksi Wanita. Jogjakarta: A plus Books

Anurogo D dan Wulandari A. 2011. Cara Jitu Mengatasi Nyeri Haid. Yogyakarta: Penerbit Andi

Blum ASS, Smith G, Sugai D, Parsa FD. 2010. Understanding endorphins and theirimportance in pain management. Hawai'IMedical Journal; 69:7071.

Kirana, D. 2011. Hubungan Asupan Zat Gizi dan Pola Menstruasi Dengan Kejadian Anemia Pada Remaja Putri. Artikel penelitian. Universitas Diponegoro.

Munandar, U. 2009. Pengembangan kreativitas anak berbakat. Jakarta: Rineka cipta 
Proverawati, A., dan Misaroh, S. 2009. Menarche Menstruasi Pertama Penuh. Makna. Yogyakarta: Nuha Medika.

Renityas N, Tinasari L. Wibisono W. 2017. Efektivitas Acuyoga Terhadap Keluhan Insomnia Pada Ibu Primigravida di Masyarakat Agriculture. Jurnal Ners dan Kebidanan. Vol.4, no.2. hh.98-103

Rohimawati, R. 2011. Sehat dan Bahagia dengan Yoga. Jakarta: Kawan Pustaka.

Rokade PB. 2011. Release of endomorphinhormone and its effects on our body admoods : a review.
International Conferenceon Chemical, Biological dan Enviroment Sciences; 2011 Dec; Bangkok : ICCEBS

Sormin NM. 2014. Efektivitas senam dismenore dalam mengurangi dismenore pada remaja putri di smp negeri 2 Siantan Kabupaten Pontianak. Proners Jurnal Keperawatan.vol. 1, no.1, hh.1-8.

Suratini. 2013. Panduan Praktikum Keperawatan Keluarga. STIKes Aisyiah. Yogyakarta

Sarwono SW. (2013). Psikologi Remaja. Edisi Revisi. Jakarta: PT. Raja Gravindo. 